\title{
Is Every Respiratory Failure a Myasthenic Crisis?
}

\author{
${ }^{1}$ Engin Özakın, ${ }^{1}$ Atilla Özcan Özdemir, ${ }^{1}$ Ebubekir Asrlan, ${ }^{1}$ Nurdan Acar, \\ ${ }^{1}$ Filiz Baloğlu Kaya \\ ${ }^{1}$ Eskişehir Osmangazi Üniversitesi, Tıp Fakültesi, Acil Anabilim Dalı, Eskişehir \\ *email: enginozakin@ hotmail.com
}

\begin{abstract}
Myasthenic crisis is respiratory failure from myasthenic weakness. Due to the involvement of respiratory muscles, hypoventilation can occur and subsequently lead to hypoxia and hypercapnia. This paper presents a 82-year-old patient with a past medical history of myasthenia gravis who presented to the emergency department with complaints of asthenia and shortness of breath. Why should an emergency physician be aware of this: In patients presenting to a hospital due to shortness of breath, blood gas and D-dimer test results should be evaluated carefully. PE should be suspected in myasthenia gravis patients with hypocapnia and high D-dimer results. The patient was diagnosed with pulmonary embolism given the high value of D-dimer and hypocapnic blood gas.
\end{abstract}

KEYWORDS: Myasthenic crisis, Pulmonary embolism, D-dimer, Arterial blood gase.

\section{HER SOLUNUM YETMEZLİ̆̈I MYASTENIK KRİZ Mİ?}

ÖZET: Myastenik kriz solunum kaslarında güçsüzlüğe bağlı solunum yetmezliği tablosudur. Solunum kaslarının etkilenmesi sonucu hipoksi ve hiperkapniye neden olan hipoventilasyon oluşur. Bu yazıda, myastenia gravis tanısı olan, 82 yaşında halsizlik ve nefes darlığı ile acil servise başvuran hasta sunuldu. Neden acil hekimi bunun farkında olmalı: Hastaneye nefes darlığı, nedeni ile başvuran hastalarda, kan gazı ve D-dimer test sonuçları dikkatle ele alınmalı. D-dimer yüksekliği ve hipokapni saptanan myastenia gravis hastalarında Pulmoner emboli akla getirilmelidir. ANAHTAR KELIMELER: Myastenik kriz, pulmoner emboli, D-dimer, Arter kan gazı

\section{Introduction}

Myastenia gravis (MG) an autoimmune disorder of the neuromuscular junction tends to be characterized by remissions and exacerbetions. Myasthenic crisis is a serious complication and life-threatening condition of MG and is defined as weakness from acquired MG that is severs enough to require intubation (1)

\section{Case Report}

A 82-year-old male patient was seen in the emergency department due to excessive sleepiness and fatigue. He was diagnosed with myasthenia gravis (MG) fifteen years ago and currently on Pyridostigmine bromide. It was reported that the patient was suffered from oral intake disorder, excessive sleepiness and occasional speech disorder for ten days and that was aggravated in the last two days.

The physical examination showed that his general health condition was moderate, he was dormant, and he had slight shortness of breath. The vital signs were as follows: blood pressure $130 / 80 \mathrm{mmHg}$, heart rate $64 / \mathrm{min}$, respiratory rate $20 / \mathrm{min}$, body temperature $36.3^{\circ} \mathrm{C}$ and saturation $92 \%$. In the respiratory system examination, there were rales in the form of crepitation in both basal hemithoraxes and bilateral $+1 /+1$ pretibial edema was detected. 
The laboratory test results did not reveal any pathologies excluding the following ones: blood glucose: $170 \mathrm{mg} / \mathrm{dl}$, arterial blood gas analysis: pH: 7.4, pCO2:26 mmHg, pO2:51.3 $\mathrm{mmHg}$, sat: $89 \%$, Cardiac enzymes: myoglobin: $98 \mathrm{ng} / \mathrm{ml}$, CK-MB: $2.88 \mathrm{ng} / \mathrm{ml}$, troponin $\mathrm{T}: \quad 0.117 \mathrm{ng} / \mathrm{ml}(0-0.014)$. The electrocardiogram showed normal sinus rhythm. No sign was detected in direct chest XRay, excluding atelectasic changes. Bedside echocardiography showed medium-level systolic dysfunction, ejection fraction of 35\%, mild tricuspid insufficiency and pulmonary arterial pressure of $40-45 \mathrm{mmHg}$. In addition to myasthenic crisis, a diagnosis of pulmonary embolism, new-onset heart failure or atypical pneumonia was considered regarding to these findings. The Geneva risk scoring was used to determine the probability of pulmonary embolism (PE) (table 1), and with the score of 8 , the test indicated moderate probability of pulmonary embolism (PE). In order to exclude the diagnosis of PE, D-dimer test was performed and the result was found as 22100 U. In respect to his Geneva scoring suggesting a moderate probability of pulmonary embolism and the higher D-dimer value, CT angiography of the thorax was performed. Bilateral sub massive pulmonary embolism was reported in the CTA (figure 1). The plan was to transfer the patient to the intensive care unit of chest diseases. However, because of the tachypnea (30/min), tachycardia (120/min) and the worsening of clinical condition, the patient was intubated electively under sedoanalgesia and a patient was connected portable disposable ventilator. Afterwards, intravenous rt-tPA was administered. Due to the development of cardiac arrest during the treatment, CPR was done. However, the patient was accepted as exitus since no response was achieved.

Table 1

The Geneva Score

\begin{tabular}{ll}
\hline & Risk factors \\
\hline Age & 1 \\
$60-79$ years & 2 \\
80+ years & 2 \\
Previous venous thromboembolism & \\
Previous DVT or PE & 3 \\
Previous surgery & \\
Recent surgery within 4 weeks & 1 \\
Heart rate & \\
Heart rate $>100$ beats per minute & 2 \\
PaCO2 & 1 \\
$<35 \mathrm{mmHg}$ & \\
$35-39 \mathrm{mmHg}$ & 4 \\
PaO2 & 3 \\
$<49$ mmHg & 2 \\
$49-59$ mmHg & 1 \\
$60-71$ mmHg & \\
$72-82 \mathrm{mmHg}$ & 1 \\
Chest X-ray findings & 1 \\
Band atelectasis & \\
Elevation of hemidiaphragm & \\
\hline$<5$ points indicates a low probability of PE, 5-8 points indicates a moderate probability of PE, >8 points \\
indicates a high probability of PE
\end{tabular}




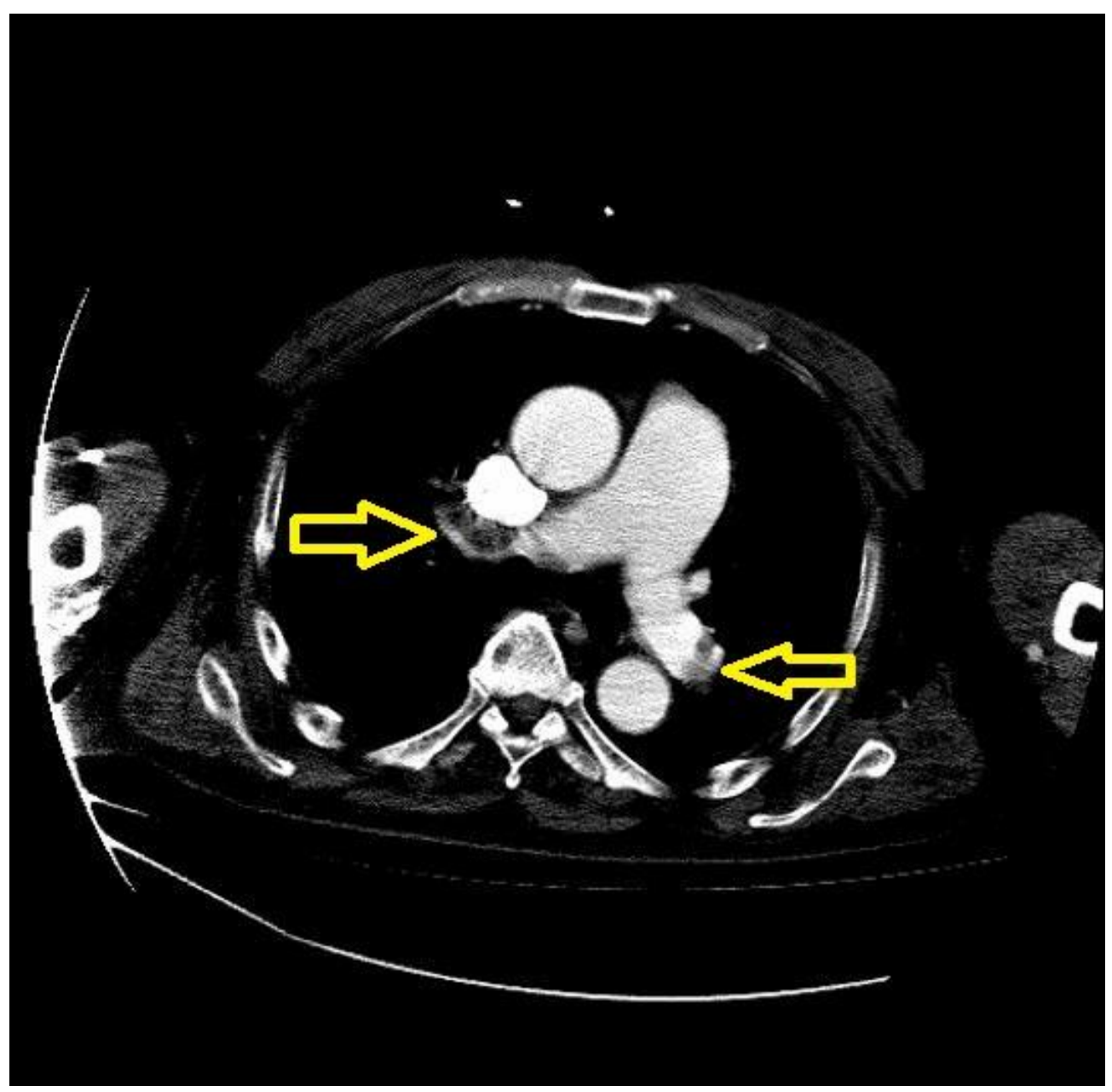

Figure 1. Bilateral submassive pulmonary embolism

\section{REFERENCES}

1. Kirmani JF, Yahia AM, Qureshi Aİ., (2004). Myasthenic crisis. Curr Treat Options Neurology. 6(1):3-15.

2. Thomas JE, Mater SA, Gungor Y, Swarup R, Webster EA, Chang I., (1997). Myasthenic crisis: Clinical features, mortality complications and risk factors for prolonged intubation. Neurology 48(5):1253-1260.

3. Putman MR, Wise RA., (1996). Myasthenia gravis and upper airway obstruction. Chest. 109(9):400-404.

4. Mayer SA., (1997). Intensive care of the myasthenic patient. Neurology.;48(5):70-75

5. Mehta S., (2006). Neuromuscular disease causing acute respiratory failure. Respir Care. 51(9):1016.

6. Sharshar T, Chevret S, Bourdain F, Raphaël JC, French., (2003). Early predictors of mechanical ventilation in Guillain-Barrésyndrome. Cooperative Group on Plasma Exchange in
Guillain-BarréSyndrome. Crit Care Med. 31(1):278

7. N, CarpenèN, Gherardi M., (2009). Chronic respiratory care for neuromuscular diseases in adults. Ambrosino Eur Respir J. 34(2):444.

8. Kyrle PA, Eichinger S., (2005). Deep vein thrombosis. Lancet 2005, 365:1163-1174

9. Anderson FA Jr, Spencer FA., (2003). Risk factors for venous thromboembolism. Circulaiton 2003;107 (23 Suppl.1):I9-16

10. http://www.ehealthme.com/Review: could Myasthenia gravis cause Fibrin d dimer increased? 